\title{
Treatment of surface water contaminated arsenite using continuous flow air-cathode electrocoagulation
}

\author{
Daniya Bisara ${ }^{1}$, Rofiq Iqbal $^{1}$, and Syarif Hidayat ${ }^{1^{*}}$ \\ ${ }^{1}$ Faculty of Civil and Environmental Engineering, Institut Teknologi Bandung, Indonesia
}

\begin{abstract}
Air-cathode Electrocoagulation (ACEC) is a new emerging technology that combines the concepts of electrocoagulation and fuel cell technology for treating water contaminated by pollutants without the addition of external energy. In this study, the ACEC reactor was used for the removal of Arsenite $\left(\mathrm{As}^{3+}\right)$ contained in river water. The effects of the different anode materials and hydraulic retention time (HRT) to the performance of the reactor were investigated. The water containing $3,5 \mathrm{ppm}$ of arsenite was used as a representation of river water contaminated by heavy metal. Three types of metal plates (magnesium, iron, and aluminum) were used as anode materials, while a wet-proof (30\%) carbon cloth used as a cathode electrode. The reactor performance was evaluated by measuring the removal efficiency of arsenite, metal hydroxide concentration, current density, and maximum power density of the reactor. The result showed that the ACEC reactor with iron, aluminium, and magnesium anode were able to remove $99 \%, 17 \%$, and $73 \%$ of arsenite respectively. In further experiments, the reactor was conducted in continuous mode with 4,8 , and 12 hours of HRT. The ACEC reactor with 12 hours HRT was able to remove arsenite up to $99 \%$ for 24 hours. This result indicated that ACEC process is a promising technology for the effective removal of arsenite from aqueous solution without additional energy.
\end{abstract}

\section{Introduction}

The occurrence of arsenic in drinking water sources currently use surface water sources is a worldwide problem. Arsenic is a carcinogenic metal that is found in surface water and naturally found in surface water, especially in waters exposed to a volcanic eruption. However, the concentration of arsenic in waters has increased with the development of the industry [1].

Arsenic can provide harm to the body because it is carcinogenic. The arsenic metal can cause diseases such as respiratory system disorders, gastrointestinal disorders, skin cancer, disorders of the nerves, to obstructive pulmonary disease.

Several previous studies have found to treat heavy metal such as ion-exchange, adsorption, chemical precipitation, and electrocoagulation. Electrocoagulation technology is a technology that is widely used because it has high allowance effectiveness [2]. However, electrocoagulation is more suitable for use in urban areas than in rural areas because it needs some external electricity supply. For this reason, modifications are made through new technology, namely Air-Cathode Cell Electrocoagulation (ACEC) which in its application does not require external energy so it is expected to be more economical compared to the conventional electrocoagulation technology [3]. The reaction is shown in the following reactions.

Cathode : $1 / 2 \mathrm{O}_{2}+2 \mathrm{H}^{+}+2 \mathrm{e}^{-} \rightarrow \mathrm{H}_{2} \mathrm{O}$

Anode $: \mathrm{M}_{(\mathrm{s})} \rightarrow \mathrm{M}_{\mathrm{aq}}^{+}+\mathrm{e}^{-}$

Recently, ACEC treatment for arsenic removal has been investigated by some research groups $[4,5,6]$. These groups used ACEC to remove 1 liter of $1 \mathrm{mg} / \mathrm{L} \mathrm{As}(\mathrm{V})$ with an air cathode and a carbon cloth. In this research, we investigated the effectiveness of ACEC technology in the removal of arsenite (As(III)) without supporting electrolyte addition. Most of As(III) removal needs to convert As(III) to As(V) to get higher efficiency [7].

The performance of ACEC reactor with different anode materials, initial $\mathrm{pH}$, and HRT to investigate the most effectiveness conditions in the mechanism of arsenite removal in water. In addition, the electrical potential that can be generated from the arsenite removal process using ACEC technology was analyzed. Most importantly, we provided a performance evaluation of diverse methods with respect to arsenite removal efficiency, current electricity produced, and the maximum power density of the reactor.

\section{Methods}

\subsection{Reactor construction}

The reactor used was made of acrylic material with a total volume of $75 \mathrm{ml}$ (Figure 1). Three types of metal plates were used as an anode electrode (aluminum, iron, and magnesium). Each plate has a thickness of $2 \mathrm{~mm}$ with an area of $25 \mathrm{~cm}^{2}$. A wet-proof (30\%) carbon cloth used as a cathode electrode. The source of arsenic metal was $\mathrm{As}^{3+}$ species from the solution of $\mathrm{NaAsO}_{2}$. The concentration of arsenic was $3.5 \mathrm{ppm}$ refers to the maximum arsenic concentration found in surface water in the Ciwidey Area, Bandung, Indonesia.

\subsection{Reactor operation}

In the first experiment, the reactor was operated in the fed batch-recirculation mode using a peristaltic pump with a

\footnotetext{
*Corresponding author: shidayat@tl.itb.ac.id
} 
flow rate of $75 \mathrm{ml} / \mathrm{min}$ with an external resistance of $20 \Omega$. The volume of treated water was 2.0 liters. The sample was taken for $0.5,1.0,2.0,3.0,4.0,8.0,18$, and 24 hours. The species of the arsenic i.e. arsenite and arsenate were also analyzed. In the further experiment the reactor was operated in the continuous flow mode with 4, 8, 12 hours of HRT. The reactor was operated using magnesium metal plate as the best anode material.

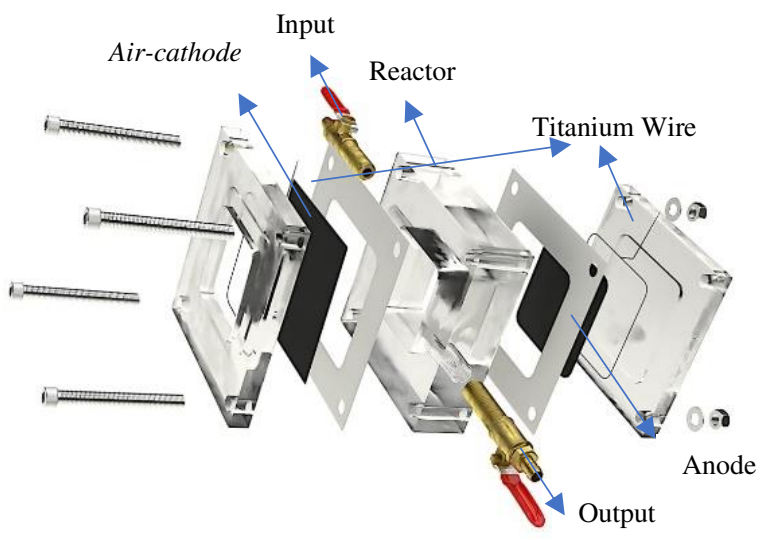

Fig. 1. Air-cathode electrocoagulation reactor.

\subsection{Analysis and Calculation}

Parameters analyzed were arsenic concentration and anode metal plates dissolved in the system. The treated water sample is filtered to separate the dissolved metal from the formed precipitate. Then the samples were analyzed using AAS (Atomic Absorption Spectroscopy).

As(III) analysis was performed using colorimetric method on the basis of spectrometry. Total arsenic concentrations of $(\mathrm{As}(\mathrm{III})+\mathrm{As}(\mathrm{V})$ were determined using an (AAS) atomic adsorption spectrometer (SCIEX Perkin Elmer Elan mode 5000).

For the analysis of precipitate formed using FTIR (Fourier Transform Infrared Spectroscopy) and SEM-EDS (Scanning Electron Microscope-Energy Dispersive X-Ray Spectroscopy). Precipitate analysis was carried out to prove that the arsenite removal process has changed from a solution to a solid.

To measure the electrical potential in the ACEC reactor, the cathode and anode were connected to a voltmeter using a $1 \mathrm{~mm}$ diameter titanium wire. To analyze the electricity production from the reactor, the current and voltage data were collected. Those data used for polarization curve analysis to see the maximum electricity generated on the reactor. The polarization curve was made of two variables, current density and power density which the calculations use the following equation.

$$
\begin{aligned}
& I=\frac{V}{R_{e x}} \\
& i=\frac{I}{A} \\
& P=V \times I \\
& p=\frac{P}{A}
\end{aligned}
$$

Where $I$ is current, $R_{\text {ex }}$ is external resistance, $i$ is current density, $\mathrm{A}$ is area, $\mathrm{P}$ is power, $\mathrm{p}$ is power density. The polarization curve is made by varying external resistance (20-15,000 $\Omega$ ). From the analysis of the polarization curve obtained the maximum value of power density.

\section{Results and discussion}

\subsection{Characterization of ACEC-produced precipitate}

At first, arsenite solution was clear and colorless. During the process, flocs will be produced and turned the solution into a turbid and reddish-brown solution. Based on research from [4], the removal of As (III) through the oxidation process of As (III) to As (V), followed by coprecipitation of As $(\mathrm{V})$ with the anode metal hydroxides [4].

$\mathrm{Fe}(\mathrm{OH})_{3}(\mathrm{~s})+\mathrm{AsO}_{3}{ }^{-4}(\mathrm{aq}) \rightarrow\left[\mathrm{Fe}(\mathrm{OH})_{3} \cdot \mathrm{AsO}_{3}{ }^{-4}\right](\mathrm{s})$
$\mathrm{Al}(\mathrm{OH})_{3}(\mathrm{~s})+\mathrm{AsO}_{3}{ }^{-4}(\mathrm{aq}) \rightarrow\left[\mathrm{Al}(\mathrm{OH})_{3} \cdot \mathrm{AsO}_{3}{ }^{-4}\right](\mathrm{s})$
$\mathrm{Mg}(\mathrm{OH})_{2}(\mathrm{~s})+\mathrm{AsO}_{3}{ }^{-4}(\mathrm{aq}) \rightarrow\left[\mathrm{Mg}(\mathrm{OH})_{2} \cdot \mathrm{AsO}_{3}{ }^{-4}\right](\mathrm{s})$

Based on Figure 2(a), It shows the broad $\mathrm{O}-\mathrm{H}$ stretching band in the 3000 to $3700 \mathrm{~cm}^{-1}$ range. The peak at 3695.61 and $3448.72 \mathrm{~cm}^{-1}$ reflects hydroxyl groups and their corresponding $-\mathrm{OH}$ stretching for magnesium hydroxide and oxyhydroxides phases. The absorptions within $1340-1470 \mathrm{~cm}^{-1}$ correspond to $\mathrm{C}-\mathrm{H}$ stretching vibrations. The peak at $864.11 \mathrm{~cm}^{-1}$ was assigned to the symmetric stretching vibrations of $\mathrm{As}(\mathrm{V})-\mathrm{O}$ structural units [8].

Figure 2(b) shows the iron-arsenic by-product. The bands at 3404.36 and $2964.59 \mathrm{~cm}^{-1}$ are generally assigned to $\mathrm{OH}$ stretching. Bands for hydroxyl bending and $\gamma(\mathrm{OH})$ water bending vibration showed up at $1631.78 \mathrm{~cm}^{-1}$ [8]. Lepidocrocite phase, magnetite $\left(\mathrm{Fe}_{3} \mathrm{O}_{4}\right)$, and $\mathrm{Fe}-\mathrm{O}$ at 1101.35, 1631.78, and $468.70 \mathrm{~cm}^{-1}$, respectively. Lepidocrocite was the main product of iron and $\mathrm{NaCl}$ reaction [8]. The $804.32 \mathrm{~cm}^{-1}$ band was assigned by Loehr and Plane [9] to the stretching vibration of the As-O bond.

Based on Figure 2(c), it shows that there is a wide O$\mathrm{H}$ stretch in the range of 3000 to $3700 \mathrm{~cm}^{-1}$. The peak at $3412 \mathrm{~cm}^{-1}$ reflects the hydroxyl group and the $-\mathrm{OH}$ stretch which is thought to be aluminum hydroxide and shows the boehmite characteristics. While the peaks at 1440 and $1631 \mathrm{~cm}^{-1}$ correspond to the vibrations of the boehmite amorphous group. Meanwhile, the peak at $812.03 \mathrm{~cm}^{-1}$ is indicated as an As (V) -O structural unit [8].

The SEM (Scanning Electron Microscope) technique has most widely been used to identify the morphology of electrocoagulation precipitate. In this research, the SEM was used to investigate the morphology of the ACEC precipitate produced during the process. Based on the SEM analysis in the Figure 3, the precipitate produced has superb porosity with the size was $\sim 100 \mathrm{~nm}$. It can be classified into nanopores and micropores. Due to the larger surface, the metal oxide/oxyhydroxides can adsorb the arsenite aqueous easily [5]. 


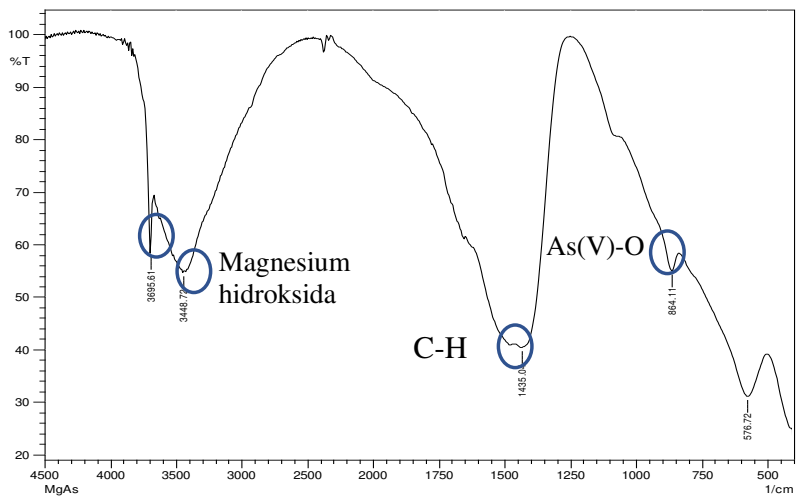

(a)

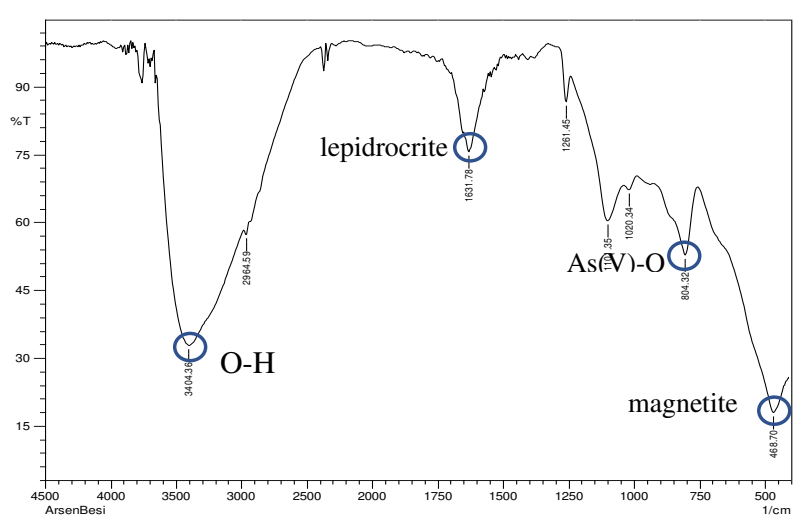

(b)

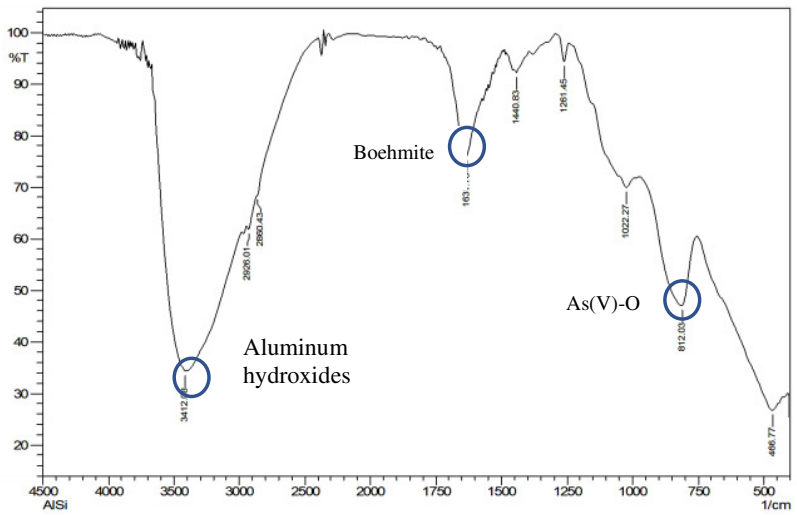

Fig. 2. Basic characterization of ACEC precipitate using FTIR (a)magnesium-arsenic precipitate analysis (b)iron-arsenic precipitate analysis (c)aluminum-arsenic precipitate analysis.

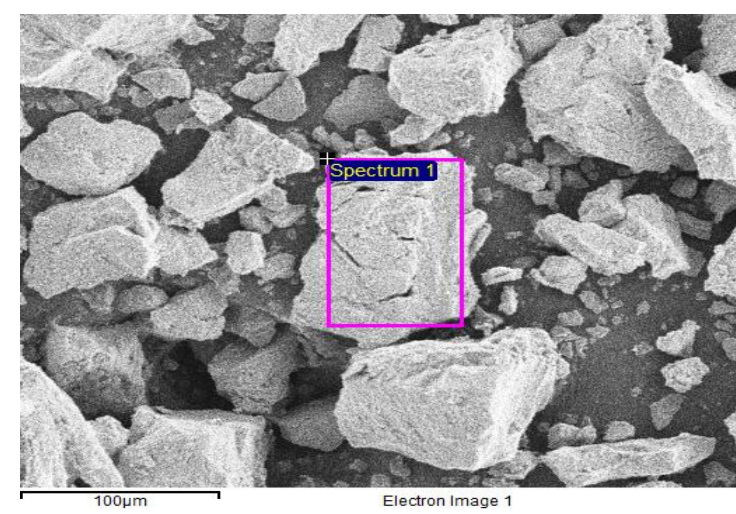

Fig. 3. SEM analysis of ACEC produced precipitate.
The EDX analysis in Figure 4 showed the ACEC precipitate confirmed the presence of $\mathrm{Fe}, \mathrm{As}$, and oxygen (O) as a major element. The weight percentages of $\mathrm{Fe}, \mathrm{As}$, and $\mathrm{O}$ were $62.05,6.63$, and $31.32 \%$, respectively. The appearance of arsenic peaks in the EDX spectrum after the As treatment suggests that the As should be adsorbed on the surface of the iron-oxyhydroxides

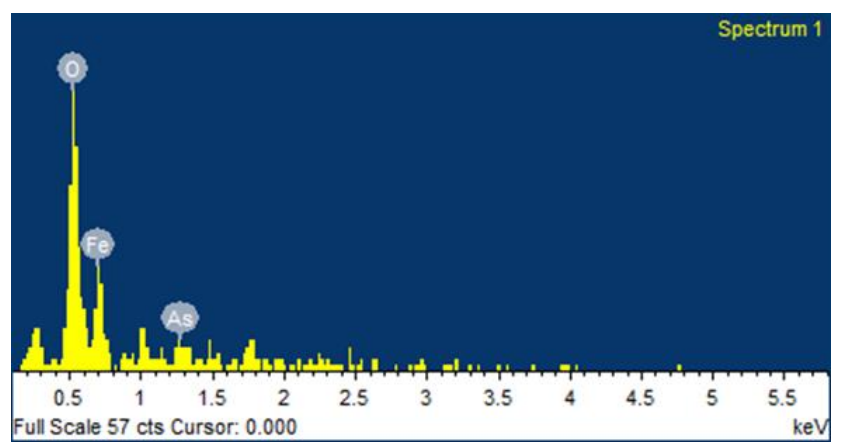

Fig. 4. EDX analysis of ACEC produced precipitate.

\subsection{Power and current density production in ACEC reactor with different anode}

The effects of anode was investigated by variying the magnesium, iron, and aluminum plate. To distinguish with the previous research, the arsenite treatment was investigated without supporting electrolyte. This type of research was conducted to explore the practicality of ACEC system to treat drinking water in remote areas. Because it is found that the need for electrolyte is one of the major challenges to expand the use of ACEC systems. Therefore, in this work, we explore the possibility to optimize the system with low conductivity, referring to the characteristics of the real river.

Based on the Figure 5, the highest current produced was about $1.8 \mathrm{~mA}$ by magnesium plate. Aluminum and iron were lower of about 0.15 and $0.25 \mathrm{~mA}$.

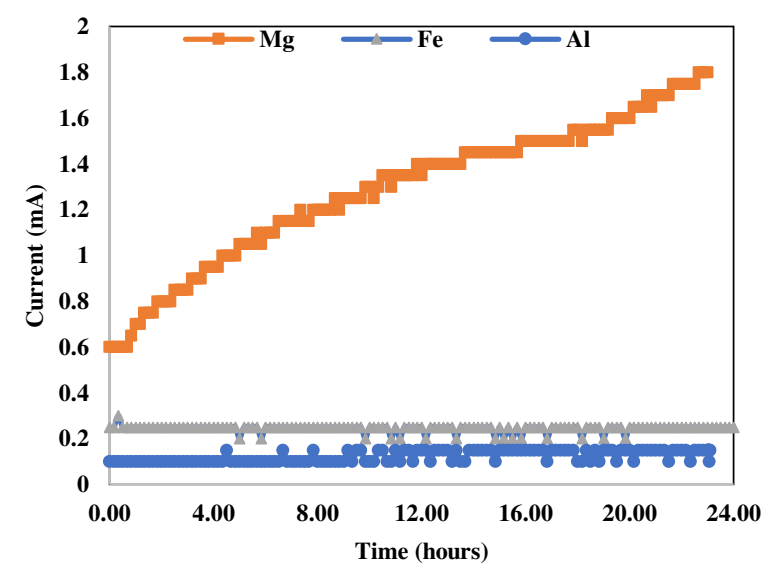

Fig. 5. The current produced with time (2 Liter of $\mathrm{NaAsO}_{2}, \mathrm{pH}$ 7).

Figure 6 showed that the highest power density production reached by magnesium plate $0.103 \mathrm{~W} / \mathrm{m}^{2}$. Comparing to alumunium and iron plate which have value 0.004 and $0.011 \mathrm{~W} / \mathrm{m}^{2}$. Magnesium has the smallest redox potential value $\left(-2.37 \mathrm{E}^{0}\right)$, compared to aluminum $(-1.66$ 
$\left.\mathrm{E}^{0}\right)$ and iron $\left(-0.44 \mathrm{E}^{0}\right)$. The tendency for metals to oxidize increases if the redox potential value becomes smaller. This makes magnesium most reactive so that the highest electrons are produced.

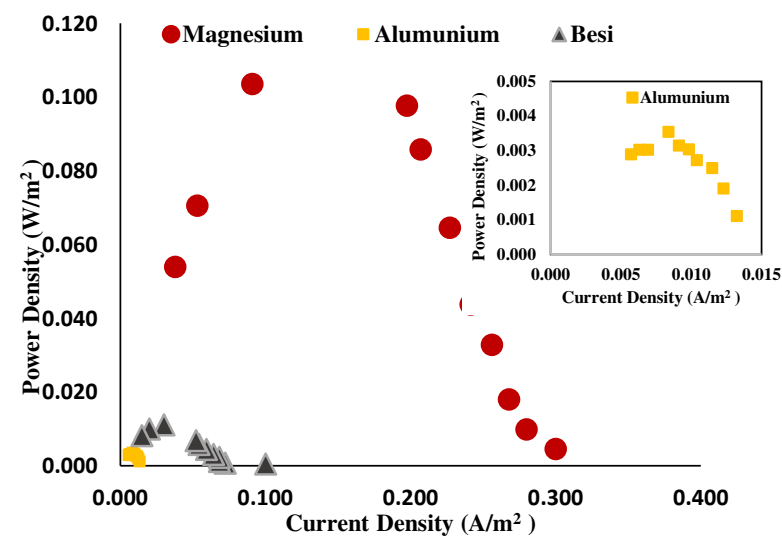

Fig. 6. Power density versus current density for magnesium, aluminum, and iron anode (Insert : aluminum anode).

\subsection{Performance of ACEC reactor with different anode materials}

In this experiment, the conductivity of the solution was adjusted around $30-50 \mu \mathrm{S} / \mathrm{cm}$. The initial $\mathrm{pH}$ was neutral (7) and the initial arsen concentration was $3.5 \mathrm{ppm}$.

In the removal of As(III) process, the concentration of $\mathrm{As}(\mathrm{V})$ and total arsenic was also detected. It is seen from Figure. 7 that the $\mathrm{As}(\mathrm{V})$ was produced and the concentration of $\mathrm{As}(\mathrm{V})$ increased with the reaction time and subsequently decreased with the time.

In Figure 7, iron anode has the best performance among others anode plate. Iron can remove arsen until $<0.05 \mathrm{ppm}$ in 24 hours. Comparing with aluminum and magnesium plate which still leaves arsenic concentration around $2.8 \mathrm{ppm}$ and $0.9 \mathrm{ppm}$, respectively. Based on equation 7-9, the removal of arsenic is directly linked to the rate of coagulant formation with the oxidation of the metal anode electrode. It can be explained with the solubility coefficient number of the three anodes (Table 1). $\mathrm{Fe}(\mathrm{OH})_{3(\mathrm{~s})}$ has the smallest solubility constant among others so it will be produced first and can remove arsenite faster than others.

Table 1. Solubility constant of metal hydroxides.

\begin{tabular}{|l|c|c|}
\hline Compound & Solubility Constant $\mathrm{K}_{\mathrm{sp}}$ & Reference \\
\hline $\mathrm{Fe}(\mathrm{OH})_{3(\mathrm{~s})}$ & $4 * 10^{-38}$ & {$[10]$} \\
\hline $\mathrm{Al}(\mathrm{OH})_{3(\mathrm{~s})}$ & $1.3 * 10^{-33}$ & \\
\hline $\mathrm{Mg}(\mathrm{OH})_{2(\mathrm{~s})}$ & $1.8 * 10^{-11}$ & \\
\hline
\end{tabular}

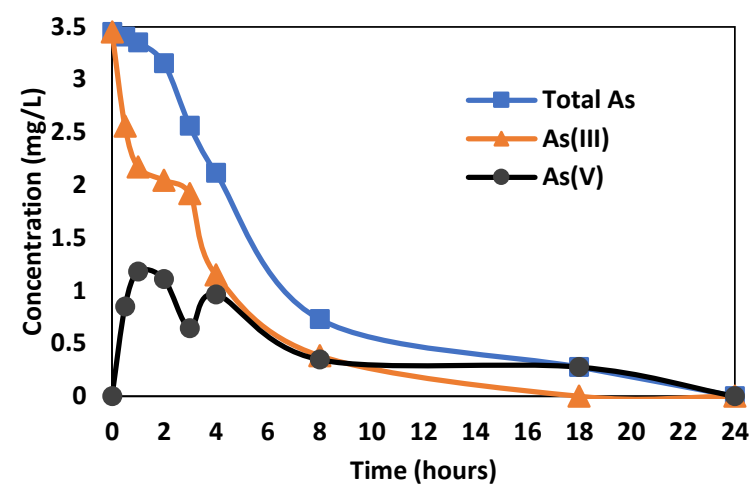

(a)

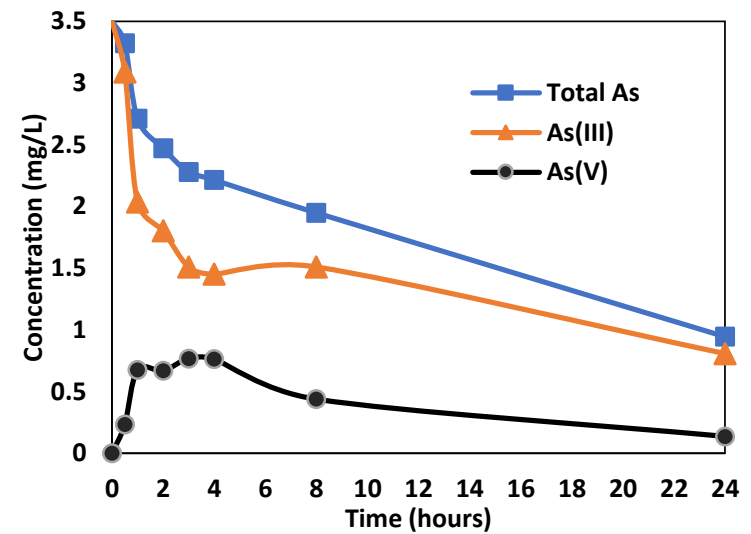

(b)

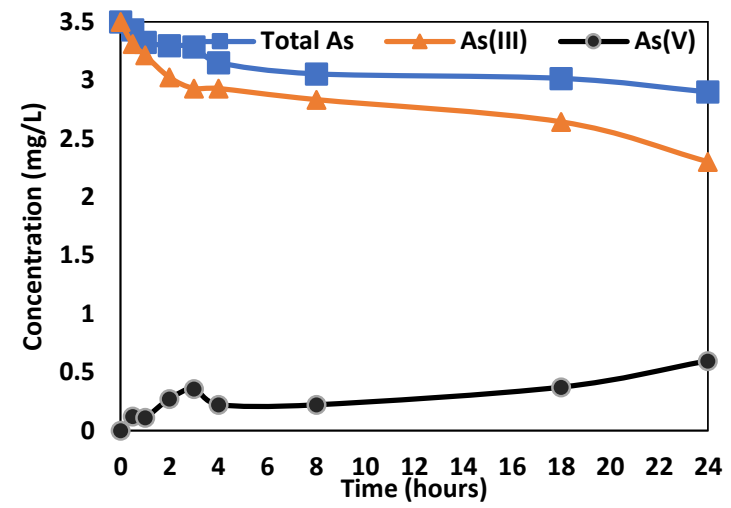

(c)

Fig. 7. Arsenic concentration versus time (initial $\mathrm{pH} 7$, external resistance $20 \Omega$ ); (a) iron, (b) magnesium (c) aluminum.

And also based on its characteristics, the highest electronegativity value of iron compared to the other two metals. Iron electronegativity is 1.83 , while aluminum and magnesium are 1.5 and 1.3, respectively. Electronegativity is a chemical property that explains the ability of an atom to attract electrons to itself to form covalent bonds.

Based on these results, the research for continuous systems uses iron anode to get the highest arsenite removal efficiency.

\subsection{Performance of ACEC reactor with different Hydraulic Retention Time}

In the continuos flow experiments, the effect of hydraulic retention time (HRT) on arsenite removal was examined by varying the HRT (4 hour, 8 hour, 12 hour). The initial 
$\mathrm{pH}$ used was 7, initial arsenite concentration was $3.5 \mathrm{ppm}$, and the resistance was $20 \Omega$. From the experiments, it can be seen that hydraulic retention times variation gives effect to arsenite removal. An increase in HRT increased the arsenite removal efficiency. From Figure 8, HRT 4, 8, and 12 hour give $42 \%, 50 \%$, and $99 \%$ arsenite removal, respectively. This is due to the longer HRT value or slower inlet flow rate, the higher the formation rate of stable metal hydroxides and the longer the contact time between metal hydroxide and arsenite. It can also enhance the precipitation of the arsenite solution.

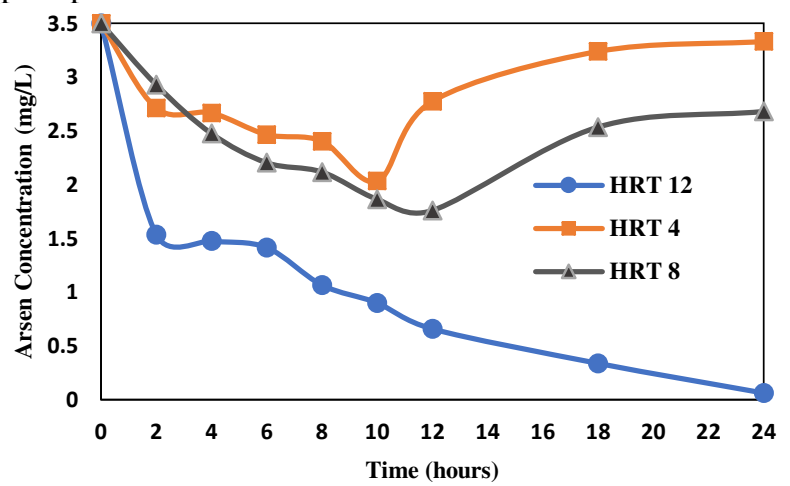

Fig. 8. Arsenite removal concentration versus time.

The effects upon power density and electrical current density of HRT variation was also investigated (Figure 9). The power density in 12 hour HRT $\left(0.00013 \mathrm{~W} / \mathrm{m}^{2}\right)$ was the lowest compared to 8 hour HRT $\left(0.011 \mathrm{~W} / \mathrm{m}^{2}\right)$ and 4 hour HRT $\left(0.016 \mathrm{~W} / \mathrm{m}^{2}\right)$. It can be concluded from the result that HRT impacts on electricity generation. This phenomenon can be happen because the longer of HRT and slower inlet flow rate, the lower the arsenite ions concentration to be treated. So, it will decrease the transportation of electron inside the reactor and impact the generation of electricity.

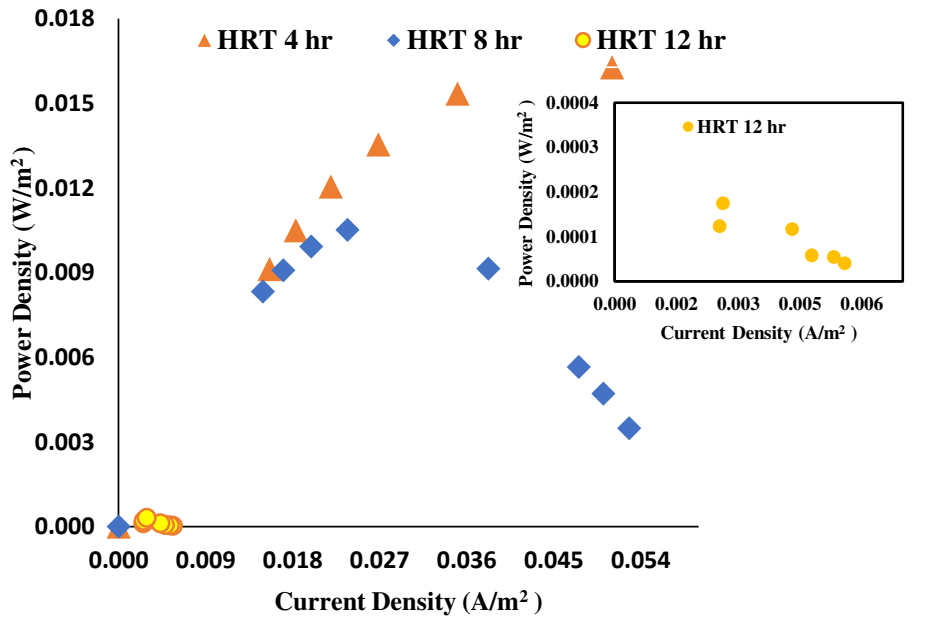

Fig. 9. Power density versus current density for varied HRT 4 hr, $8 \mathrm{hr}, 12 \mathrm{hr}$ (Insert : HRT 12 hour).

In recent years, ACEC shows the greatest potential for application in the treatment of arsenic. The comparison of ACEC performance shows in Table 2. In previous research, ACEC can remove $\mathrm{As}(\mathrm{V})$ up to $99 \%$ using the supporting electrolyte. In this experiment, ACEC also proved that it can remove $\mathrm{As}$ (III) both in recirculationbatch and continuous flow until $99 \%$ even without supporting electrolyte addition using iron anode.

Table 2. Comparison of ACEC technology.

\begin{tabular}{|c|c|c|c|c|c|c|c|c|c|}
\hline No. & $\begin{array}{l}\text { Feed } \\
\text { mode }\end{array}$ & Anode & $\begin{array}{l}\text { Capa } \\
\text { city } \\
(\mathrm{L})\end{array}$ & Heavy metal & $\begin{array}{l}\text { Operational } \\
\text { condition }\end{array}$ & $\begin{array}{l}\text { Duration of } \\
\text { treatment } \\
\text { (hours) }\end{array}$ & $\begin{array}{l}\text { Power } \\
\text { Density } \\
\left(\mathrm{W} / \mathrm{m}^{2}\right)\end{array}$ & $\begin{array}{c}\text { Removal } \\
\text { efficiency } \\
(\%)\end{array}$ & $\begin{array}{l}\text { Refe } \\
\text { rence }\end{array}$ \\
\hline 1 & $\begin{array}{l}\text { Recir } \\
\text { culation }\end{array}$ & Iron & 20 & \multirow{7}{*}{$1 \mathrm{~L}, 1 \underset{(\mathrm{Vp})}{\mathrm{ppm}} \mathrm{As}$} & $\begin{array}{c}100 \text { mM NaHCO3, } \\
\text { pH } 5\end{array}$ & 4 & 5.9 & 99.5 & {$[11]$} \\
\hline 2 & Batch & Iron & 0.09 & & $\begin{array}{l}60 \mathrm{mM} \mathrm{NaHCO} 3 \\
50 \mathrm{~mL} \mathrm{NaCl}, \mathrm{pH} 5\end{array}$ & 6 & 1.99 & 99.9 & {$[12]$} \\
\hline 3 & \multirow{5}{*}{$\begin{array}{l}\text { Recir } \\
\text { culation }\end{array}$} & Iron & 20 & & 10 mM NaCl, pH 7 & 0.5 & 0.238 & 100 & {$[4]$} \\
\hline 4 & & Iron & 1 & & 10 mM NaCl, pH 7 & 4 & 0.18 & 99.6 & [4] \\
\hline 5 & & Iron & 1 & & $\begin{array}{c}10 \mathrm{mM} \\
\mathrm{NaCl}+10 \mathrm{mM} \\
\mathrm{Na} 2 \mathrm{SO} 4, \mathrm{pH} 7\end{array}$ & 8 & 0.52 & 100 & {$[4]$} \\
\hline 6 & & $\begin{array}{c}\text { Alumuniu } \\
\mathrm{m}\end{array}$ & 1 & & 10 mM NaCl, pH 7 & 4 & 0.112 & 99.9 & {$[5]$} \\
\hline 7 & & $\begin{array}{c}\text { Alumuniu } \\
\mathrm{m}\end{array}$ & 1 & & $\begin{array}{c}10 \mathrm{mM} \mathrm{NaCl}+8 \mathrm{mM} \\
\mathrm{Na} 2 \mathrm{SO} 4, \mathrm{pH} 7\end{array}$ & 24 & 0.308 & 98.5 & {$[5]$} \\
\hline 8 & \multirow{3}{*}{$\begin{array}{l}\text { Recir } \\
\text { culation }\end{array}$} & Iron & 0.075 & $\begin{array}{c}2 \mathrm{~L}, 3.5 \mathrm{ppm} \\
\text { As (III) }\end{array}$ & \multirow{3}{*}{$\begin{array}{l}\text { Without supporting } \\
\text { electrolyte, } \mathrm{pH} 7\end{array}$} & 24 & 0.011 & 99 & $\begin{array}{l}\text { This } \\
\text { study }\end{array}$ \\
\hline 9 & & $\begin{array}{c}\text { Alumuniu } \\
\mathrm{m}\end{array}$ & 0.075 & $\begin{array}{c}2 \mathrm{~L}, 3.5 \mathrm{ppm} \\
\text { As (III) }\end{array}$ & & 24 & 0.004 & 17 & $\begin{array}{l}\text { This } \\
\text { study }\end{array}$ \\
\hline 10 & & $\begin{array}{l}\text { Magne } \\
\text { sium }\end{array}$ & 0.075 & $\begin{array}{c}2 \mathrm{~L}, 3.5 \mathrm{ppm} \\
\text { As (III) }\end{array}$ & & 24 & 0.103 & 73 & $\begin{array}{l}\text { This } \\
\text { study }\end{array}$ \\
\hline
\end{tabular}




\begin{tabular}{|c|c|c|c|c|c|c|c|c|c|}
\hline No. & $\begin{array}{c}\text { Feed } \\
\text { mode }\end{array}$ & Anode & $\begin{array}{c}\text { Capa } \\
\text { city } \\
\text { (L) }\end{array}$ & Heavy metal & $\begin{array}{c}\text { Operational } \\
\text { condition }\end{array}$ & $\begin{array}{c}\text { Duration of } \\
\text { treatment } \\
\text { (hours) }\end{array}$ & $\begin{array}{c}\text { Power } \\
\text { Density } \\
\left(\mathrm{W} / \mathrm{m}^{2}\right)\end{array}$ & $\begin{array}{c}\text { Removal } \\
\text { efficiency } \\
(\%)\end{array}$ & $\begin{array}{c}\text { Refe } \\
\text { rence }\end{array}$ \\
\hline 11 & $\begin{array}{c}\text { Continuo } \\
\text { us }\end{array}$ & Iron & 0.075 & $\begin{array}{c}0.15 \mathrm{~L} \text { (HRT } \\
12 \mathrm{hr}), 3.5 \mathrm{ppm} \\
\text { As (III) }\end{array}$ & $\begin{array}{c}\text { Without supporting } \\
\text { electrolyte, } \mathrm{pH} 7\end{array}$ & 24 & 0.0013 & 99 & $\begin{array}{c}\text { This } \\
\text { study }\end{array}$ \\
\hline
\end{tabular}

\subsection{Anode concentration and $\mathrm{pH}$ during arsenite removal process}

Anode concentration analysis was used to know the concentration of dissolved metal ions on the solution during the process. Dissolved metal ions were produced due to the oxidation of the anode electrode. The dissolved metal ions then formed stable metal hydroxides and oxyhydroxides in the solution. In general, As(III) removal in ACEC depended on ionic conductivity and the concentration of stable metal hydroxides and oxyhydroxides generated in the solution.

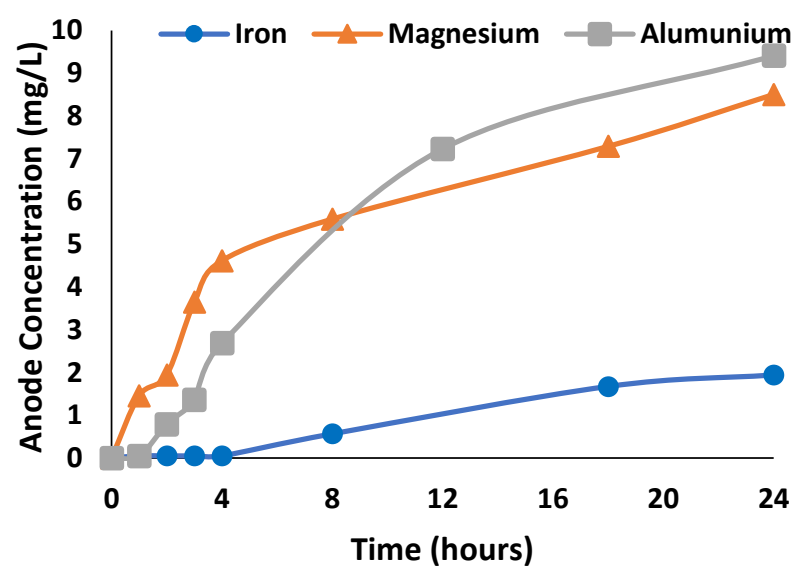

Fig. 10. Anode concentration during the process.

Based on Figure 10, iron ions on the solution were the lowest than other metals. Possibly it happens because, iron ions reaction with $\mathrm{OH}^{-}$to form iron- hydroxides was fastest than aluminum and magnesium ions. It also explains the arsenite removal using iron anode was the highest efficiency.

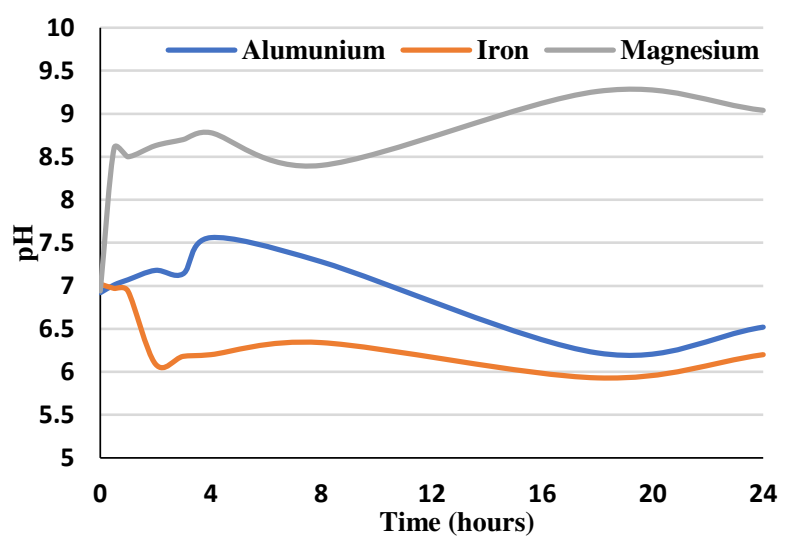

Fig. 11. $\mathrm{pH}$ during arsenite removal.

In arsenite removal, $\mathrm{pH}$ was a fundamental factor influencing the electrocoagulation process. $\mathrm{pH}$ can improve the buffer capacity of the solution. Arsenite and anode metal ions can exist in a solid form under acidic conditions. Based on Figure 11, the $\mathrm{pH}$ of iron and aluminum anode was stable around 6-7. The iron's pH constantly decreasing during the process because the $\mathrm{OH}^{-}$ion on the cathode was consumed to produce iron hydroxides with the iron ions.

\section{Conclusion}

In this study, the ACEC reactor was used for the removal of Arsenite $\left(\mathrm{As}^{3+}\right)$ contained in surface water. The effects of the different anode material and hydraulic retention time (HRT) to the performance of the reactor were investigated. Based on the precipitate analysis, the existence of arsenic was confirmed. The characterization shows that there were magnesium hydroxide and $\mathrm{As}(\mathrm{V})-\mathrm{O}$ for magnesium-arsen precipitate and also there were lepidocrocite phase, magnetite $\left(\mathrm{Fe}_{3} \mathrm{O}_{4}\right), \mathrm{Fe}-\mathrm{O}$, and also As-O bond for iron-arsenic precipitate. Iron has the highest effectiveness (99\%) in the arsenite removal process compared to the two other types of metal plates, because it has the lowest solubility constant which can make the metal hydoxides binding with arsenite more easily. However, for electricity production, magnesium is the highest one because magnesium has the lowest potential redox and very reactive so that the highest electrons are produced.

\section{References}

[1] Nidheesh, P. V. Dan Singh, T. S. A. (2017) "Arsenic Removal By Electrocoagulation Process: Recent Trends And Removal Mechanism," Chemosphere, 181, Hal. 418-432. Doi: 10.1016/J.Chemosphere.2017.04.082.

[2] Kobya, M. Et Al. (2011) "Treatment Of Potable Water Containing Low Concentration Of Arsenic With Electrocoagulation: Different Connection Modes And Fe-Al Electrodes," Separation And Purification Technology, 77, Hal. 283-293. Doi: 10.1016/J.Seppur.2010.12.018.

[3] Tian, Y. Et Al. (2016) "Energy Efficient Electrocoagulation Using An Air-Breathing Cathode To Remove Nutrients From Wastewater," Chemical Engineering Journal. Elsevier B.V., 292, Hal. 308314. Doi: 10.1016/J.Cej.2016.02.004.

[4] Kim, J. H., Maitlo, H. A. and Park, J. Y. (2017) "Treatment Of Synthetic Arsenate Wastewater With Iron-Air Fuel Cell Electrocoagulation To Supply Drinking Water And Electricity In Remote Areas," Water Research. Elsevier Ltd, 115, Hal. 278-286. Doi: 10.1016/J.Watres.2017.02.066.

[5] Maitlo, H. A. Et Al. (2018) "Effects Of Supporting Electrolytes In Treatment Of Arsenate-Containing 
Wastewater With Power Generation By Aluminumair Fuel Cell Electrocoagulation," Journal Of Industrial And Engineering Chemistry. Elsevier, 57, Hal. 254-262. Doi: 10.1016/J.Jiec.2017.08.031.

[6] Maitlo, H. A. Et Al. (2019) "Metal-Air Fuel Cell Electrocoagulation Techniques For The Treatment Of Arsenic In Water," Journal Of Cleaner Production. Elsevier Ltd, 207, Hal. 67-84. Doi: 10.1016/J.Jclepro.2018.09.232.

[7] Banerji, T. and Chaudhari, S. (2016) "Journal Of Environmental Chemical Engineering Arsenic Removal From Drinking Water By Electrocoagulation Using Iron Electrodes- An Understanding Of The Process Parameters," Biochemical Pharmacology. Elsevier B.V., 4(4), Hal. 3990-4000. Doi: 10.1016/J.Jece.2016.09.007.

[8] Gomes, J. A. G. et al. (2007) "Arsenic removal by electrocoagulation using combined Al-Fe electrode system and characterization of products," Journal of Hazardous Materials, 139, hal. 220-231. doi: 10.1016/j.jhazmat.2005.11.108.

[9] Loehr, T. M., and Plane, R. A., Inorg. Chem. 7, 1708 (1968).

[10] Petrucci, H. R., Herring, F. G. and Madura, J. D. (2017) General Chemistry Principles and Modern Application Seventh Edition. Seventh Ed. Diedit oleh C. O'Donnell. Ontario: Pearson Canada Inc.

[11] Maitlo, H. A., Kim, J. H. and Park, J. Y. (2017) "Chemosphere Arsenic treatment and power generation with a dual-chambered fuel cell with anionic and cationic membranes using NaHCO 3 anolyte and $\mathrm{HCl}$ or $\mathrm{NaCl}$ catholyte," Chemosphere. Elsevier Ltd, 172, hal. 138-146. doi: 10.1016/j.chemosphere.2016.12.149.

[12] Kim, J. H., Park, I. S. and Park, J. Y. (2015) "Electricity generation and recovery of iron hydroxides using a single chamber fuel cell with iron anode and air-cathode for electrocoagulation," Applied Energy. Elsevier, 160, hal. 18-27. doi: 10.1016/J.APENERGY.2015.09.041. 